\title{
Nibrin Double Strand Breakage and its Role in Development of Cancers
}

\author{
Fizza Abidi ${ }^{1}$ \\ Mervyn Hossein ${ }^{2}$ \\ Saima Akram ${ }^{3}$ \\ Angabeen Anjum ${ }^{4}$
}

BDS

FDSRCS(Ed), FDSRCS, FFDRCSI

BSc, BDS, MDS

BDS

The human genetic information has been orchestrated by DNA-damage response pathways. DNA damage response, DNA repair,programmed apoptosis and cell cycle progession are responsible for maintaining the genomic integrity, they initiates the process of tumorigenesis if they are not regulated properly.An article research was done through Google Scholar, Pubmed and was used for an electronic search of articles, using the following keywords: Double stranded breakage, Nibrin, P95, NBS1.The aim of the review is to point out the impact of double strand breakage and the role of Nibrin in development of cancers. The double strand breakage are pathological insults for all the microorganisms because they can cause the elimination of the essential genetic information, which results in the destruction of DNA replication Nibrin is the first DNA repair gene whose overexpression can promotes the process of tumorigenesis by the activation of phosphoinositol 3 kinase /akt pathways.

KEYWORDS: Nibrin, Double strand breakage, P95, NBS1.

HOW TO CITE: Abidi F, Hossein M, Akram S, Anjum A. Nibrin double strand breakage and its role in development of cancers. J Pak Dent Assoc 2020;29(2):94-99.

DOI: https://doi.org/10.25301/JPDA.292.94

Received: 18 April 2019, Accepted: 17 February 2020

\section{INTRODUCTION}

$\mathrm{T}$ he integrity of the human genome is maintained by DNA damage response pathways which includes DNA repairing, chromatin remodelling, cell cycle checkpoint regulation and apoptosis. ${ }^{1-3}$ There are different types of DNA damage repair pathways which include Nucleotide excision repair (NER) pathway, Base excision repair pathway(BER), Mismatch excision repair(MER) pathway and Double strand breakage repair (DSB) pathway and if these pathways are not regulated properly then leads to the process of tumourigenesis. ${ }^{4}$

The DNA repair mechanism failure and the risk factor for the familial genetic cancer had been established earlier, from last 20 years studies had reported the possible association of genetic polymorphism and cancer formation. ${ }^{5}$

An electronic article search was done by using keywords Nibrin, NBS1, DNA Damage Response Pathway (DDR) and P95on Google Scholar, PubMed. Different types of research articles including original, review, clinical observation, case

1. Lecturer/Mphil trainee, Department of Pathology, Ziauddin College of Dentistry.

2. Principal, Ziauddin College of Dentistry.

3. HoD, Associate Professor, Department of Oral Pathology, Ziauddin College of Dentistry.

4. Mphil trainee, Department of Oral Pathology, Ziauddin College of Dentistry. Lecturer Sir Syed Medical College for Girls.

Corresponding author: “Dr. Fizza Abidi” < dentistrulz12@gmail.com > reports, longitudinal studies and randomized con trolled trials were selected. The aim of the review is to point out the impact of double-strand breakage and the role of Nibrin in development of cancers.

The double-strand breakages are pathological insults for all microorganisms because they can cause the gain or loss of the essential genetic information, leading to the genetic transformation which provokes the process of tumourigenesis.

DNA replication stress are the main causative factor for endogenous double strand breakage. The double strand breakage are responsible for the destruction of the genetic information by lethal metabolites includes UV radiation, products of cellular metabolism, harmful chemicals and toxins. Scientist has been working for the last 40 years to discover the specific critical role of DSB to understand the phenomenon..$^{5-7}$ There are 800 DNA damages occurring per hour, estimated upto 19,200 DNA damages occurring daily. ${ }^{8,9}$ In humans, The DNA damage may increase the process of tumour formation if they remain unchecked. There are different pathways to conserve the integrity of the human genome by controlling the DNA damage repair and controlling the program cell death. ${ }^{4,10}$

The Double strand breakage of DNA consists of 2 important pathways: Non-homologous end joining (NHEJ) and the Homologous repair pathway, In non homologous 
pathway DNA breaks down occurs and the broken DNA strand is covered by specific enzymes.The Non-homologous repair are independent on homologous template, the double strand breakage are detected by sensor proteins, that causes activation of proximal kinases such as ATM and MRN complex ., However, Nibrin plays an pivotal role by controlling the enzymatic activity of these proteins ( MRE 11 and Rad 50) by identifying the damage sites in DoubleStranded Breakages within 5 minutes that is called as Nibrin relocalization, Nibrin is phosphorylated by ATM in response to DNA damage that is called as Nibrin phosphorylation, this process of phosphorylation plays an important role in cell cycle $S$ phase checkpoint activation. ${ }^{11-13}$

Homologous repair are error-free whereas they require homologous template such as sister chromatid. The DNA end-resection enzymes which includes MRE11-RAD50NBS1(MRN complex), the CtIP, Exonuclease 1 plays an important role in the formation of single stranded DNA, Whereas RAD 18 involves in the process of translation of DNA synthesis. The non-homologous end-joining contains the group of DNA dependent protein kinases (kuo, ligases, nuclease, and polymerase) which are responsible for converting the non-ligating proteins to ligating protein in the presence of factors for protein alignment which act as a caretaker for genomic stability and chromosomal aberrations in the immune system. Thus, DNA ligases IV are the characteristic hallmark of the NHEJ pathways.Deficiency of DNA ligase IV will increase the immunodeficiency and radiosensitivity in the phenotypes and are known as NIJMEGEN BREAKAGE SYNDROME in which there is a defective formation of a protein called Nibrin. ${ }^{14-16}$

The nibrin protein interacts with functional proteins like ataxia-telangiectasia associated protein(ATR), histones modifying enzymes such as RNF20 and chromatin remodelling granules (nucleolin). These useful interactions perform a major role in DSB pathways and a pivotal role in cell cycle regulation. ${ }^{9}$

Nibrin/p95/ NBS1 is a protein formed by a defective gene NBS gene and it is an important member of the DNA double-strand break (DSB) repair complex (hMre11 complex) located on human chromosome 8q21 and act as a cell cycle s phase checkpoint. ${ }^{8}$

The MRN complex a trimeric combination ofMre11, $\operatorname{Rad} 50, \&$ NBs1. This Nibrin containing protein complex plays a crucial role in regulating numerous phases of doublestrand breakage and repair pathways. ${ }^{17,18}$

A 754 amino acid containing protein Nibrin, consists of three districts: the $\mathrm{N}$-end containing forkhead-associated domain and two breast cancer-associated domains ( BRCA and carboxy-terminal BRCT), a Central region containing Ataxia telangiectasia mutated kinase (ATM Kinase) and
C-terminal for the binding site of MRN complex (MRE 11 and ATM binding Domain). Recent investigations showed that greater than 600 polymorphism variants of Nibrin gene had been reported. ${ }^{17,19}$

Researchers have reported that more than 10 mutations of Nibrin had been observed earlier and are more frequent in Polish and Czech populations. However, the most frequent mutation of Nibrin is 5 base pair deletion (657del5) in the NBS1 gene which is accountable for a

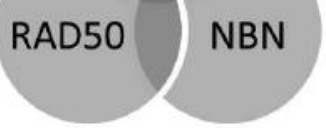

MRN COMPLEX reduction of protein size, i.e. truncation of the Nibrin protein (p95) into two uneven reduced protein fragments which include $\mathrm{p} 26$ and p70. (NIBRIN). ${ }^{11,20,21}$

Nibrin acts as a guardian maintaining genomic stability because it is a presenter of chromosomal dysfunction. Any mutation in the MRN complex due to SNPS or reduction in full length nibrin protein formation stimulates the process of double-strand breakage by increasing the mis-localizationof Mre11 and Rad 50 in the cytoplasm of the cells. All these cyclic events cause a deficiency of protein kinases, which stimulates the formation of Nijmegen breakage syndrome. ${ }^{12,22}$

The Nijmegen syndrome is an autosomal recessive disorder specified by a mutation in the N BN gene, loss of chromosomal stability, increased insensitivity to ionization radiation, immunodeficiency, mental retardation and ovarian insufficiency. The major life-threatening complication of Nijmegen syndrome is lymphoma in childhood. ${ }^{23-25}$

\section{ACTIVATION OF NIBRIN}

Nibrin is activated by proto-oncogenes such as C-MYC. The function of C-MYC includes diverse cellular functions such as cell formation and maintains the integrity of cellular metabolism. Deregulated overexpression of c-myc occurs in a broad range of human cancers and is often associated with aggressive, poorly differentiated phenotypes. Overexpression of oncoprotein C-MYC is associated with cancer formation in humans, which further stimulates the overexpression of Nibrin which causes downstream Activation of Phosphatidylinositol (PI) 3-kinase/Akt pathway, this pathway regulates the cellular proliferation, cellular growth and cellular survival., Phosphatidylinositol (PI) 3-kinase causes down-regulation of tyrosine kinase growth receptors. and activation of phosphorylation of Akt (protein kinase BPKB) controls the cell proliferation and survival proteins e.g. glycogen synthase kinase-3, GSK3,BAD and cell growth proteins.Thus PI3-kinase/Akt pathway regulates processes which are associated with tumourigenesis, any mutation or 
Table: Role of nibrin in different cancers

\begin{tabular}{|c|c|c|c|c|}
\hline & Association Type & Reference & Molecule impact on subject & Results \\
\hline 1 & NEUROGENESIS & $\begin{array}{l}\text { Zhou et } \\
\text { al..2012 }\end{array}$ & $\begin{array}{l}\text { Mutation in the nibrin } \\
\text { gene causes increase in } \\
\text { brain apoptosis and } \\
\text { reduce brain } \\
\text { proliferation by the DNA } \\
\text { damage response thus } \\
\text { plays a pivotal role in } \\
\text { embryonic neurogenesis } \\
\text { in mice( culture) }\end{array}$ & $\begin{array}{l}\text { Increase in } \\
\text { Neurodevelopmental } \\
\text { defect(microcephaly and brain } \\
\text { tumour). }\end{array}$ \\
\hline 2 & $\begin{array}{l}\text { Association of } \\
\text { Nibrin variants in } \\
\text { Breast Cancer }\end{array}$ & \begin{tabular}{|l} 
Jennifer Gass \\
et al 2017
\end{tabular} & $\begin{array}{l}\text { Heterozygous Mutation } \\
\text { in the nibrin gene can } \\
\text { initiate the process of } \\
\text { breast cancer formation } \\
\text { in the invasive ductal } \\
\text { carcinoma patient. }\end{array}$ & $\begin{array}{l}\text { The risk factor for the breast } \\
\text { and skin cancer had been } \\
\text { increased due to the mutation } \\
\text { in Nibrin variant. }\end{array}$ \\
\hline 3 & $\begin{array}{l}\text { Association of the } \\
\text { nibrin gene (NBN) } \\
\text { variants with } \\
\text { breast eancer }\end{array}$ & \begin{tabular}{|l|} 
HAKAN \\
UZUNOGLU1, \\
, et al 2015
\end{tabular} & $\begin{array}{l}\text { The most common } \\
\text { variant in Turkish } \\
\text { population responsible } \\
\text { for exuberating breast } \\
\text { cancer in younger age } \\
\text { women is } \mathrm{NBN} \text { gene } 924 \\
\mathrm{~T}>\mathrm{C} .\left(x^{2}=5.722, \mathrm{P}=0.017\right) .\end{array}$ & $\begin{array}{l}\text { Mutation in the Nibrin } \\
\text { variants } 924 \mathrm{~T}>\mathrm{C} \text { increased the } \\
\text { risk factor for genetic } \\
\text { transformation of breast } \\
\text { cancer. }\end{array}$ \\
\hline 4 & $\begin{array}{l}\text { Association of } \\
\text { Nibrin gene in } \\
\text { prostate eancer }\end{array}$ & $\begin{array}{l}\text { C. Cybulski, } \\
2004\end{array}$ & $\begin{array}{l}\text { NBS1 } 657 \text { del5 mutation } \\
\text { was found in prostate } \\
\text { cancer cases in } 9 \% \text { males } \\
\text { with familial prostate } \\
\text { cancer (odds ratio, } 16 \text {; } \\
\text { P=0.0001). }\end{array}$ & $\begin{array}{l}\text { These findings suggest that } \\
\text { heterozygous Nbs1 mutation } \\
\text { exhibit increased sensitivity to } \\
\text { prostate cancer }\end{array}$ \\
\hline 5 & $\begin{array}{l}\text { In gastric } \\
\text { careinomas }\end{array}$ & \begin{tabular}{|l} 
Naoki Ikari \\
2018
\end{tabular} & $\begin{array}{l}\text { Muatation in the NBN. } \\
\text { p.P6S in the gastric } \\
\text { cancer patient. }\end{array}$ & $\begin{array}{l}\text { Researchers had reported that } \\
\text { nibrin plays an important role } \\
\text { in lymph node metastasis in } \\
\text { gastric carcinoma by } \\
\text { increasing the process of } \\
\text { lymphangiogenesis. }\end{array}$ \\
\hline 6 & $\begin{array}{l}\text { NBN Mutations in } \\
\text { fertility defects }\end{array}$ & $\begin{array}{l}\text { Mathilde } \\
\text { Warcoin, } \\
2009\end{array}$ & $\begin{array}{l}\text { In male patient there was } \\
\text { a fertility defect, but the } \\
\text { female patient was } \\
\text { suffering from Premature } \\
\text { ovarian failure }\end{array}$ & $\begin{array}{l}\text { Deficiency of MRN complex } \\
\text { (nibrin) causes reduction in } \\
\text { meiotic recombination repair } \\
\text { pathways which leads to } \\
\text { infertility defects in humans. }\end{array}$ \\
\hline 7 & In fertility defeets & \begin{tabular}{|l|} 
Simone \\
Diflippantonio \\
2005
\end{tabular} & $\begin{array}{l}\text { In humanized male } \\
\text { mouse it causes the sperm } \\
\text { count reduction by } \\
\text { increasing the process of } \\
\text { apoptosis. Whereas in } \\
\text { humanized female mouse } \\
\text { reduction in oocyte } \\
\text { maturation stages had } \\
\text { been observed }\end{array}$ & $\begin{array}{l}\text { NBS1 required for the process } \\
\text { of sperm formation and for } \\
\text { proper meiotic division }\end{array}$ \\
\hline 8 & In OSCC & Hsu 2009 & $\begin{array}{l}\text { Raised in expression of } \\
\text { Nibrin in } 148 \text { osce patients } \\
\text { and } 58 \text { non oral cavity - } \\
\text { Head and neck squamous } \\
\text { cell carcinoma patients. }\end{array}$ & $\begin{array}{l}\text { Among OSSC patients } \\
\text { expression of nibrin observed } \\
\text { as } 39.2 \% \text { whereas in NO- } \\
\text { HNSCC expression of NBS1 } \\
\text { noted as } 53.5 \% \text {,which clearly } \\
\text { indicates that the raised in } \\
\text { nibrin expression act as an } \\
\text { independent marker of poor } \\
\text { prognosis. These results indicate } \\
\text { the possible application of } \\
\text { NBS1 in OSCC and NO- } \\
\text { HNSCC, irrespective from its } \\
\text { primary sites. }\end{array}$ \\
\hline 9 & In OsCC & $\begin{array}{l}\text { Jigna H. } \\
\text { Dave, } \\
2016\end{array}$ & $\begin{array}{l}\text { Raised in expression of } \\
\text { Nibrin in } 100 \mathrm{OSCC} \\
\text { cancer patients. }\end{array}$ & $\begin{array}{l}\text { The study included the OSCC } \\
\text { cancer patients from stage } \\
\mathrm{I}=20 \% \text {, where as stage } 2 \\
\text { include } 22 \% \text { cancer patients, } \\
\text { stage } 3 \text { include }-18 \% \text { and stage } \\
4 \text { include } 40 \% \text {.However there }\end{array}$ \\
\hline
\end{tabular}

\begin{tabular}{|c|c|c|c|c|}
\hline & & & & $\begin{array}{l}\text { tumor tissues }(\mathrm{P}=0.028) \text {, while } \\
\text { significant inversely co related } \\
\text { with tumour size and grade }(\mathrm{P}= \\
0.018)(\mathrm{P}-0.039) \text {. Moreover } \\
\text { increased in Nibrin labelling } \\
\text { index is directly associated with } \\
\text { the cancer recurrence.(P } \\
=0.049) \text {.I was concluded that, } \\
\text { In the initial stages of } \mathrm{OSCC} \\
\text { diagnosis, Nibrin could be used } \\
\text { as a prognostic biomarker. }\end{array}$ \\
\hline 10 & $\begin{array}{l}\text { In laryngeal } \\
\text { cancer }\end{array}$ & $\begin{array}{l}\text { Iwona } \\
\text { Ziólkowska, } \\
2007\end{array}$ & $\begin{array}{l}\text { The frequency of NBS1 } \\
\text { 117IV genetic mutation } \\
\text { carriers, in the group of } \\
\text { Laryngeal Cancer and } \\
\text { Multiple Primary Tumour } \\
\text { cancer patients, }\end{array}$ & $\begin{array}{l}\text { The incidence of laryngeal, } \\
\text { lung,head and neck cancers, } \\
\text { along with development of } \\
\text { second malignancies had been } \\
\text { increased due to mutation of } \\
\text { nibrin gene in Crech } \\
\text { population } \\
(\mathrm{OR}=2.43),(\mathrm{Cl}=.64-9.28) \\
(\mathrm{P}=0.28) \text {. }\end{array}$ \\
\hline 11 & $\begin{array}{l}\text { In laryngeal } \\
\text { cancer and head } \\
\text { and neck cancer }\end{array}$ & $\begin{array}{l}\text { Iwona } \\
\text { Ziólkowska, } \\
2012\end{array}$ & $\begin{array}{l}\text { Laryngeal cancer } \\
\text { incidence were reported in } \\
\text { GGTTAA, ACCCGT } \\
\text { genotypic } \\
\text { recombination. }(p<.0001) \\
\text { Whereas, GGCCAA and } \\
\text { GCCCGT genotypic } \\
\text { recombination were } \\
\text { associated with an } \\
\text { increased risk of primary } \\
\text { head and neck cancer } \\
\text { (p<.0001) }\end{array}$ & $\begin{array}{l}\text { In the Czech population Nibrin } \\
\text { mutation causes increased } \\
\text { Laryngeal cancer, lung cancer } \\
\text { metastasis and } \mathrm{HN} \text { cancer } \\
\text { formation. }\end{array}$ \\
\hline 12 & In lymphoma & $\begin{array}{l}\text { MARTIN } \\
\text { STANULLA } \\
2000\end{array}$ & $\begin{array}{l}109 \text { younger patients with } \\
\text { non-Hodgkin's lymphoma } \\
\text { (NHL) had been assessed } \\
\text { for the } 657 \text { del5 nibrin } \\
\text { genetic mutation. No } \\
\text { significant results had } \\
\text { been obtained. }\end{array}$ & $\begin{array}{l}\text { Mutation in Nibrin did not } \\
\text { played any significant role in } \\
\text { the pathogenesis of the non } \\
\text { hodgkins lymphoma in early } \\
\text { childhood. }\end{array}$ \\
\hline 13 & Medulloblastoma & $\begin{array}{l}\text { Sophie } \\
\text { Cowman } \\
2019\end{array}$ & $\begin{array}{l}\text { Hypoxia induced } \\
\text { resistance in } \\
\text { chemo/radiotherapy in } \\
\text { peadiatric tumours } \\
\text { (Medulloblastoma cell } \\
\text { lines) }\end{array}$ & $\begin{array}{l}\text { Decreased level of Nibrin } \\
\text { (MRN complex members) } \\
\text { results in reduction of DSB } \\
\text { recognition causes increase in } \\
\text { cellular survival. }\end{array}$ \\
\hline
\end{tabular}

alteration in expression will results in tumour proliferation in human being. ${ }^{26-28}$

\section{DISCUSSION}

Nibrin plays a pivotal role in neuronal development in the brain; a mutation in the nibrin gene causes neurodevelopmental defects by increasing the apoptosis results in hampered brain growth.The DNA damage response causes microcephaly and brain tumours, thus playing a major role in embryonic development. ${ }^{29}$ Heterozygous mutation(c.698_701delAACA Nibrin variant) in the nibrin gene can initiate the process of breast cancer formation. ${ }^{30}$ However different populations have different genetic variants of nibrin but in Turkish population NBN gene $924 \mathrm{~T}>\mathrm{C}$, responsible for exacerbating breast cancer in young females Whereas NBN gene $8360 \mathrm{G}>\mathrm{C}$ variant and NBN gene 30537 $\mathrm{G}>\mathrm{C}$ variant are less significant. ${ }^{11}$ Whereas the increase in expression of nibrin was associated with the poor patient 
survival rate in a recurrent ovarian cancer trial. Moreover,nibrin act as an independent predictive marker in ovarian cancer patients in different treatment modalities (comparison of Doxorubicin therapy with Trabectin plus therapy) out of 13 DNA damaging proteins the Nibrin expression were significantly raised in Trabectin plus therapy and it was associated with poorer clinical prognosis. ${ }^{31}$ Heterozygous mutation (657del5 NBS1 allele )in the quality of nibrin gene forms will lead to increase in the mutant form of nibrin protein (NBS1) and has been recognized in both sporadic and familial instances of prostate cancers. ${ }^{32,33}$ The most prevalent variant of NBN Gene mutation is c. $657 \mathrm{del} 5$ in hereditary prostate cancers. The risk of prostate cancer development is 4.3 times higher in patients with a known familial cancer history as compared to non-cancer patients in which chances of occurrence of prostate cancer is $2.5 \%$. (34)Researchers had reported that Nibrin ( NBN P6S )plays an important role in lymph node metastasis in gastric carcinoma by increasing the process of lymphangiogenesis intramucosal gastric tumours. ${ }^{35}$ The mutation of nibrin protein can give rise to fertility defects in human males and premature ovarian failure in humans females. ${ }^{36}$ but in the mouse, it destroys seminiferous tubules by increasing the process of apoptosis and causes sperm count reduction. Whereas in the female mouse it is responsible for the failure of oocyte maturation stage in meiosis, oocytes were degenerated and were arrested in diplotene stage of meiosis. ${ }^{37}$

Squamous cell carcinoma is the most commonly recognised neoplasm of the aerodigestive tract. ${ }^{38}$ Whereas, nibrin plays a significant role in DNA repair. However,CMYC(Proto-oncogenes) causes the activation of mutant nibrin formation by increasing the process of tumorigenesis (phosphatidylinositol3-kinase (PI3 K)/Akt pathway. ${ }^{27,28,39,40}$ Thus in Esophageal Squamous Cell Carcinoma nibrin plays an independent marker for survival and is inversely correlated with the nodal status, in which increased in expression of nibrin is correlated with initial tumour stages and better survival of patients. ${ }^{39}$

In OSCC and in Non Head and Neck Squamous Cell Carcinoma, overexpression of nibrin acts as an independent marker of prognosis in advanced cancers. ${ }^{41}$ In OSCC nibrin overexpression was observed in poorly differentiated oral squamous cell tumour tissue overexpression of Nibrin in early stages of oral cancer had been associated with the disease recurrence and aggressiveness of cancer therefore it could be used as a prognostic marker for the early-stage diagnosis of OSCC. ${ }^{8}$ Nibrin mutation was shown to increase laryngeal cancer formation and secondary tumour formation in lung cancer patients along with head and neck cancer patients in Czech population whereas it does not play a role in the pathogenesis of non-Hodgkin lymphoma. ${ }^{42,43} \mathrm{In}$ medulloblastoma long term hypoxia causes decrease in the level of Nibrin and other members of MRE complex which results in chemotherapy and $\mathrm{X}$-rays resistance. ${ }^{44}$

\section{CONCLUSION}

The clinical findings presented in this review show that increased DNA damage and deficiencies in enzyme systems to repair it, are the key factors implicated in the pathogenesis of cancer formation. Among the various cancers studied in this review, we observed various patterns over and underexpression of Nibrin. This clearly indicates that the expression of Nibrin is important in cancer progression and recurrence., Nibrin is the first DNA repair gene whose overexpression is capable of transforming and promotes the process of tumorigenesis by the activation of the process of tumourigenesis( phosphoinositol 3 kinase /akt of PI3-) in human cancers Thus we conclude that the role of nibrin still requires a detailed and thorough investigations. ${ }^{8,45}$

\section{CONFLICT OF INTEREST}

None declared

\section{REFERENCES}

1. Komatsu K. NBS1 and multiple regulations of DNA damage response. J Radiat Res. 2016;57:i11-i7.

https://doi.org/10.1093/jrr/rrw031

2. Tauchi H, Matsuura S, Kobayashi J, Sakamoto S, Komatsu K. Nijmegen breakage syndrome gene, NBS1, and molecular links to factors for genome stability. Oncogene. 2002;21:8967-980. https://doi.org/10.1038/sj.onc.1206136

3. Kobayashi J, Antoccia A, Tauchi H, Matsuura S, Komatsu K. NBS1 and its functional role in the DNA damage response. DNA Repair. 2004;3:855-61.

https://doi.org/10.1016/j.dnarep.2004.03.023

4. Yao Y, Dai W. Genomic instability and cancer. J Carcinogenesis Mutagenesis. 2014;5.

5. Berardinelli F, di Masi A, Antoccia A. NBN gene polymorphisms and cancer susceptibility: a systemic review. Current genomics. 2013; $14: 425-40$.

https://doi.org/10.2174/13892029113146660012

6. Lafrance-Vanasse J, Williams GJ, Tainer JA. Envisioning the dynamics and flexibility of Mre11-Rad50-Nbs1 complex to decipher its roles in DNA replication and repair. Progr Biophysics Molecular Biol. 2015;117:182-93.

https://doi.org/10.1016/j.pbiomolbio.2014.12.004

7. Deshpande RA, Lee J-H, Arora S, Paull TT. Nbs1 converts the 
human Mre11/Rad50 nuclease complex into an endo/exonuclease machine specific for protein-DNA adducts. Molecular cell. 2016;64:593606.

https://doi.org/10.1016/j.molcel.2016.10.010

8. Dave JH, Vora HH, Trivedi TI, Ghosh NR. Nibrin expression in oral squamous cell carcinoma: association with clinicopathological parameters. J Cancer Metastasis Treat. 2016;2:436-42.

https://doi.org/10.20517/2394-4722.2015.82

9. Saito Y, Zhou H, Kobayashi J. Chromatin modification and NBS1: their relationship in DNA double-strand break repair. Genes \& genetic systems. 2015;90:195-08.

https://doi.org/10.1266/ggs.15-00010

10. Polo SE, Jackson SP. Dynamics of DNA damage response proteins at DNA breaks: a focus on protein modifications. Genes \& development. 2011;25:409-33.

https://doi.org/10.1101/gad.2021311

11. Uzunoglu H, Korak T, Ergul E, et al. Association of the nibrin gene $(\mathrm{NBN})$ variants with breast cancer. Biomedical Reports. 2016;4:369-73.

https://doi.org/10.3892/br.2016.579

12. Cerosaletti K, Wright J, Concannon P. Active role for nibrin in the kinetics of atm activation. Molecular and Cellular Biology. 2006;26:1691-99.

https://doi.org/10.1128/MCB.26.5.1691-1699.2006

13. Zhou H, Kawamura K, Yanagihara H, Kobayashi J, Zhang-Akiyama Q-M. NBS1 is regulated by two kind of mechanisms: ATM-dependent complex formation with MRE11 and RAD50, and cell cycle-dependent degradation of protein. J Radiat Res. 2017;58:487-94. https://doi.org/10.1093/jrr/rrx014

14. Lieber MR. The mechanism of double-strand DNA break repair by the nonhomologous DNA end-joining pathway. Annual Revi Biochemi. 2010;79:181-211.

https://doi.org/10.1146/annurev.biochem.052308.093131

15. Mlody B. IPSC-based Modelling of Nijmegen Breakage Syndrome 2016. (PhD dissertation)

16. Pierce AJ, Jasin M. NHEJ deficiency and disease. Molecular cell. 2001;8:1160-61.

https://doi.org/10.1016/S1097-2765(01)00424-5

17. Mendez G, Cilli D, Berardinelli F, Viganotti M, Ascenzi P, Tanzarella $\mathrm{C}$, et al. Cleavage of the BRCT tandem domains of nibrin by the 657del5 mutation affects the DNA damage response less than the Arg215Trp mutation. Int Uni Biochem Mol Biolog. 2012;64:853-61. https://doi.org/10.1002/iub.1077

18. Cerosaletti KM, Concannon P. Nibrin forkhead-associated domain and breast cancer C-terminal domain are both required for nuclear focus formation and phosphorylation. J Biolog Chemis. 2003;278:21944-51.

https://doi.org/10.1074/jbc.M211689200

19. Cilli D, Mirasole C, Pennisi R, Pallotta V, D'Alessandro A, Antoccia A, et al. Identification of the Interactors of Human Nibrin (NBN) and of Its $26 \mathrm{kDa}$ and $70 \mathrm{kDa}$ Fragments Arising from the NBN 657del5 Founder Mutation. PLoS ONE. 2014;9:(Artical ID) e114651. https://doi.org/10.1371/journal.pone.0114651

20. Cerosaletti KM, Lange E, Stringham HM, Weemaes CM, Smeets D, Sölder B, et al. Fine localization of the Nijmegen breakage syndrome gene to 8q21: evidence for a common founder haplotype. Am J Human Genetics. 1998;63:125-34.

https://doi.org/10.1086/301927

21. Varon R, Vissinga C, Platzer M, Cerosaletti KM, Chrzanowska KH, Saar K, et al. Nibrin, a novel DNA double-strand break repair protein, is mutated in Nijmegen breakage syndrome. Cell. 1998;93:46776.

https://doi.org/10.1016/S0092-8674(00)81174-5

22. Cerosaletti K, Concannon P. Independent roles for nibrin and Mre11-Rad50 in the activation and function of Atm. J Biolog Chemis. 2004;279:38813-9.

https://doi.org/10.1074/jbc.M404294200

23. di Masi A, Antoccia A. NBS1 heterozygosity and cancer risk. Current genomics. 2008;9:275-81.

https://doi.org/10.2174/138920208784533610

24. Salewsky B, Wessendorf P, Hirsch D, Krenzlin H, Digweed M. Nijmegen breakage syndrome: the clearance pathway for mutant nibrin protein is allele specific. Gene. 2013;519:217-21.

https://doi.org/10.1016/j.gene.2013.02.033

25. Wang Y, Li M, Long J, Shi X-Y, Li Q, Chen J, et al. Clinical significance of increased expression of Nijmegen breakage syndrome gene (NBS1) in human primary liver cancer. Hepatology Int. 2014;8:250-59.

https://doi.org/10.1007/s12072-013-9500-x

26. Chen Y-C, Chiang H-Y, Yang M-H, Chen P-M, Chang S-Y, Teng S-C, et al. Activation of phosphoinositide 3-kinase by the NBS1 DNA repair protein through a novel activation motif. J Molecular Medi. 2008;86:401-12.

https://doi.org/10.1007/s00109-008-0302-x

27. Chen YC, Su YN, Chou PC et al. Overexpression of NBS1 contributes to transformation through the activation of phosphatidylinositol 3-kinase/Akt. J Biolog Chemi. 2005;280:3250511.

https://doi.org/10.1074/jbc.M501449200

28. Yang M, Chang S, Chiou S et al, Liu C, Chi C, Chen P. Overexpression of NBS1 induces epithelial-mesenchymal transition and co-expression of NBS1 and Snail predicts metastasis of head and neck cancer. Oncogene. 2007;26:1459.

https://doi.org/10.1038/sj.onc.1209929

29. Zhou Z, Bruhn C, Wang Z-Q. Differential function of NBS1 and ATR in neurogenesis. DNA repair. 2012;11:210-21. https://doi.org/10.1016/j.dnarep.2011.10.021 
30. Gass J, Jackson J, Macklin S, Blackburn P, Hines S, Atwal PS. A case of contralateral breast cancer and skin cancer associated with NBN heterozygous pathogenic variant c. 698_701delAACA. Familial cancer. 2017; 16:551-53.

https://doi.org/10.1007/s10689-017-9982-0

31. Monk BJ, Kaye SB, Poveda A, Herzog TJ, Aracil M, Nieto A, et al. Nibrin is a marker of clinical outcome in patients with advanced serous ovarian cancer treated in the phase III OVA-301 trial. Gynecologi Oncolog. 2014;132:176-80.

https://doi.org/10.1016/j.ygyno.2013.10.032

32. Cybulski C, Gorski B, Debniak T, Gliniewicz B, Mierzejewski M, Masojc B, et al. NBS1 is a prostate cancer susceptibility gene. Cancer Res. 2004;64:1215-19.

https://doi.org/10.1158/0008-5472.CAN-03-2502

33. Hughes C, Murphy A, Martin C, Sheils O, O'leary J. Molecular pathology of prostate cancer. J Clin Pathol. 2005;58:67384.

https://doi.org/10.1136/jcp.2002.003954

34. Zhen JT, Syed J, Nguyen KA, Leapman MS, Agarwal N, Brierley $\mathrm{K}$, et al. Genetic testing for hereditary prostate cancer: Current status and limitations. Cancer. 2018.

https://doi.org/10.1002/cncr.31316

35. Ikari N, Aoyama S, Seshimo A, Suehiro Y, Motohashi T, Mitani $\mathrm{S}$, et al. Somatic mutations and increased lymphangiogenesis observed in a rare case of intramucosal gastric carcinoma with lymph node metastasis. Oncotarget. 2018;9:10808-17.

https://doi.org/10.18632/oncotarget.24289

36. Warcoin M, Lespinasse J, Despouy G, Dubois d'Enghien C, Laugé A, Portnoï MF, et al. Fertility defects revealing germline biallelic nonsense NBN mutations. Human mutation. 2009;30:424-30. https://doi.org/10.1002/humu.20904

37. Difilippantonio S, Celeste A, Fernandez-Capetillo O, Chen H-T, San Martin BR, Van Laethem F, et al. Role of Nbs1 in the activation of the Atm kinase revealed in humanized mouse models. Nature Cell Biolog. 2005;7:675.

https://doi.org/10.1038/ncb1270
38. Wenig BM. Squamous cell carcinoma of the upper aerodigestive tract: dysplasia and select variants. Modern Pathology. 2017;30: S112.

https://doi.org/10.1038/modpathol.2016.207

39. Kuo K-T, Chou T-Y, Hsu H-S, Chen W-L, Wang L-S. Prognostic significance of NBS1 and Snail expression in esophageal squamous cell carcinoma. Annals Surgi oncology. 2012;19:549-57. https://doi.org/10.1245/s10434-011-2043-2

40. Yang M-H, Chiang W-C, Chou T-Y, Chang S-Y, Chen P-M, Teng $\mathrm{S}-\mathrm{C}$, et al. Increased NBS1 Expression Is a Marker of Aggressive Head and Neck Cancer and Overexpression of NBS1 Contributes to Transformation. Clin Cancer Res. 2006;12:507-15. https://doi.org/10.1158/1078-0432.CCR-05-1231

41. Hsu DSS, Chang SY, Liu CJ, Tzeng CH, Wu KJ, Kao JY, et al. Identification of increased NBS1 expression as a prognostic marker of squamous cell carcinoma of the oral cavity. Cancer Sci. 2010;101:1029-37.

https://doi.org/10.1111/j.1349-7006.2009.01471.x

42. Ziolkowska I. Increased risk of larynx cancer in heterozygous carriers of the I171V mutation of the NBS1 gene. Cancer science. 2007;98:1701-05.

https://doi.org/10.1111/j.1349-7006.2007.00594.x

43. Ziolkowska-Suchanek IM. Association of polymorphisms and haplotypes of the NBN gene with laryngeal cancer and multiple primary tumors of the head and neck. Head \& neck. 2012;34:376-83. https://doi.org/10.1002/hed.21741

44. Cowman S, Fan YN, Pizer B, Sée V. Decrease of Nibrin expression in chronic hypoxia is associated with hypoxia-induced chemoresistance in some brain tumour cells. BMC cancer. 2019;19:300:1-16. https://doi.org/10.1186/s12885-019-5476-9

45. Mireles-Canales MP. DNA Damage and Deficiencies in the Mechanisms of Its Repair: Implications in the Pathogenesis of Systemic Lupus Erythematosus. J Immunol Res. 2018:(18pages). https://doi.org/10.1155/2018/8214379 